\title{
OPTIMIZATION OF FOREST AGE-DEPENDENT LIGHT-USE EFFICIENCY AND ITS IMPLICATIONS ON CLIMATE-VEGETATION INTERACTIONS IN CHINA
}

\author{
Z. $\mathrm{Li}^{\mathrm{a}, \mathrm{b}}$ and $\mathrm{T}$. Zhou ${ }^{\mathrm{a}, \mathrm{b}^{*}}$ \\ a State Key Laboratory of Earth Surface Processes and Resource Ecology, Beijing Normal University, Beijing, \\ China-zhengli@mail.bnu.edu.cn \\ b Academy of Disaster Reduction and Emergency Management, Ministry of Civil Affairs and Ministry of Education, Beijing,
} China- tzhou@bnu.edu.cn

KEY WORDS: NPP, Stand age, Maximum light-use efficiency, Climate change

\begin{abstract}
:
Forest's net primary productivity (NPP) is a key index in studying interactions of climate and vegetation, and accurate prediction of NPP is essential to understand the forests' response to climate change. The magnitude and trends of forest NPP not only depend on climate factors (e.g., temperature and precipitation), but also on the succession stages (i.e., forest stand age). Although forest stand age plays a significant role on NPP, it is usually ignored by remote sensing-based models. In this study, we used remote sensing data and meteorological data to estimate forest NPP in China based on CASA model, and then employed field observations to inversely estimate the parameter of maximum light-use efficiency $\left(\varepsilon_{\max }\right)$ of forests in different stand ages. We further developed functions to describe the relationship between maximum light-use efficiency $\left(\varepsilon_{\max }\right)$ and forest stand age, and estimated forest age-dependent NPP based on these functions. The results showed that $\varepsilon_{\max }$ has changed according to forest types and the forest stand age. For deciduous broadleaf forest, the average $\varepsilon_{\max }$ of young, middle-aged and mature forest are $0.68,0.65$ and $0.60 \mathrm{gC} \mathrm{MJ}^{-1}$. For evergreen broadleaf forest, the average $\varepsilon_{\max }$ of young, middle-aged and mature forests are $1.05,1.01$ and $0.99 \mathrm{gC} \mathrm{MJ}^{-1}$. For evergreen needleleaf forest, the average $\varepsilon_{\max }$ of young, middle-aged and mature forests are $0.72,0.57$ and $0.52 \mathrm{gC} \mathrm{MJ}^{-1}$.The NPP of young and middle-aged forests were underestimated based on a constant $\varepsilon_{\max }$. Young forests and middle-aged forests had higher $\varepsilon_{\max }$, and they were more sensitive to trends and fluctuations of climate change, so they led to greater annual fluctuations of NPP. These findings confirm the importance of considering forest stand age to the estimation of NPP and they are significant to study the response of forests to climate change.
\end{abstract}

\section{INTRODUCTION}

The vegetation is the main body of the biosphere, and it is significant to regulate the global carbon balance (Piao et al., 2001). Net Primary Production (NPP) is one of the main components of the carbon cycle (Piao et al., 2008; Liang et al., 2015) and also an indicator to the ecosystem performance (Lobell et al., 2002). Climate change has deeply affected the ecosystem and NPP has become a significant tool to reflect the variation of the ecosystem (Hao et al., 1998; Liu et al., 2015). In general, the forest ecosystem NPP accounted for $35 \%$ of the global and $65 \%$ of the terrestrial ecosystem NPP (Gower et al., 1996; Waring and Schlesinger, 1985). The variation in forest NPP will change the atmospheric $\mathrm{CO}_{2}$ concentration and further affect the climate change (Want et al., 2011). The difference in the forest stand ages and forest types are critical factors to the forest ecosystem, and it is essential to investigate the variation of the forest NPP with the forest stand ages among forest types (Chen et al., 2003; Song and Woodcock, 2003; Kashian et al., 2006). The Carnegie-Ames-Stanford Approach (CASA) model (Potter et al., 1993) based on the remote sensing data is widely used to simulate the spatial distribution of the NPP and it can also be employed to monitor NPP at different scales (Li et al., 2009). The accuracy of the estimated NPP based on the CASA model has been mostly affected by the maximum light-use efficiency $\left(\varepsilon_{\max }\right)$, and it exists differences among forest types and the forest stand ages (Zhu et al., 2006; Hui et al., 2012 ). The maximum light-use efficiency could influence the carbon sink of the ecosystem, and reflect the forest ecosystem productivity (Zhou et al., 2010). Potter and Field think that the maximum light-use efficiency of all the vegetation types around the world is $0.389 \mathrm{gC} / \mathrm{MJ}$, and Raymond et al believe that the upper limit of the maximum light-use efficiency is $3.5 \mathrm{gC} \mathrm{MJ}^{-1}$. Thus, it is essential to determine the maximum light-use efficiency based on the forest stand ages among forest types (Potter et al., 1993; Raymond et al., 1994; Field et al., 1995, 1998). In this study, the CASA model was employed to estimate NPP in China from 1982 to 2005 . We calculated the maximum light-use efficiency of forests in the forest stand ages based on the estimated NPP and the field observation NPP. The relationship between the maximum light-use efficiency and the forest stand ages could be developed to reflect the impact of change in the forest stand ages on the maximum light-use efficiency, and the estimated age-dependent NPP could also be calculated based on the relationship.

\section{DATA AND METHODS}

\subsection{Remote sensing data}

Many vegetation indices based on the remote sensing data have been developed to monitor vegetation dynamics, and the most widely used is the Normalized Difference Vegetation Index (NDVI). The NDVI dataset used in this study was obtained from the Global Inventory Modelling and Mapping Studies inventory (Tucker et al., 2005) during the period 1982 to 2005. This dataset has a long time series and it is helpful to be applied to reflect the vegetation information (Beck et al., 2011). The spatial resolution of the dataset is $8 \mathrm{~km}$, and the temporal resolution is 15 days. To match with other data, the GIMMS NDVI dataset is composited based on the maximum value composite (MVC). The MVC technique retains the highest value for each pixel, and the images are relatively cloud-free, 
with the ability to reflect the vegetation dynamics (Eidenshink, 1992; Holben, 1986).

\subsection{Meteorological data and the land cover map}

This study employed the monthly average temperature, the monthly precipitation data and the monthly total solar radiation data during the period 1982 to 2005 from the National Climate Centre of the Chinese Meteorological Administration (CMA). The homogeneity and reliability of the monthly meteorological data have been previously checked and controlled by the CMA (Yu et al., 2014). The related longitude, latitude and the altitude of the meteorological stations are also used in this study to interpolate the meteorological data based on the GIS methods. The cell size matches with the NDVI dataset. The Land Cover map used in this study was originated from the MODIS Landcover dataset, and the classification of the vegetation type was chosen type 1 (ISTP).

\subsection{Field observation data of NPP}

The NPP field observation data originates from the forest inventory data and Luo's study based on the 1266 forest plots from 1982 to 2005. It includes the forest stand age, the LAI, the total biomass, the longitude, latitude and altitude of the observation sites. It is used to correct the maximum light-use efficiency $\left(\varepsilon_{\max }\right)$ of the CASA model among different forest types in the forest stand ages. Based on the available field observation of the NPP, the forest types that considered in this study include the deciduous broadleaf forest (DBF), the evergreen needleleaf forest (ENF) and the evergreen broadleaf forest (EBF).

\subsection{CASA model}

Carnegie-Ames-Stanford Approach (CASA) model (Potter et al., 1993) can estimate monthly NPP with satellite data, monthly temperature, precipitation and soil properties (Liu et al., 2015; Zhang et al., 2015). The CASA model can simulate the spatial distribution and the variation of NPP on a regional scale and it has been widely used to monitor the NPP for various spatial scales. In CASA model, the NPP is the function of Absorbed Photosynthetic Active Radiation (APAR), the maximum light-use efficiency $\left(\varepsilon_{\max }\right)$, the effect of the temperature stress index $\left(\mathrm{T}_{\varepsilon}\right)$ and the moisture stress factor $\left(\mathrm{W}_{\varepsilon}\right)$. For a given geographic coordinate $(\mathrm{x})$ at month $\mathrm{t}, \mathrm{NPP}$ is calculated as,

$$
\operatorname{NPP}(\mathrm{x}, \mathrm{t})=\operatorname{APAR}(\mathrm{x}, \mathrm{t}) * \varepsilon(\mathrm{x}, \mathrm{t})
$$

$$
\begin{array}{r}
\operatorname{APAR}(\mathrm{x}, \mathrm{t})=\operatorname{FPAR}(\mathrm{x}, \mathrm{t}) * R_{s}(x, t) * 0.5 \\
\varepsilon(\mathrm{x}, \mathrm{t})=\varepsilon_{\text {max }}(x, t) * T(x, t) * W(x, t)
\end{array}
$$

where $R_{s}$ is the incoming shortwave radiation, FPAR is the fraction of photosynthetic active radiation absorbed by vegetation, which is determined from the satellite data (NDVI). Other model parameters, such as the annual maximum and minimum NDVI for each vegetation type, are considered corresponds to the $95 \%$ and $5 \%$ quantiles of the probability distribution of the monthly NDVI in each vegetation type (Liang et al., 2015).

\subsection{Statistical methods}

The estimate NPP based on the CASA model is largely affected by the maximum light-use efficiency $\left(\varepsilon_{\max }\right)$. In this study, we employed the field observation NPP to correct the $\varepsilon_{\max }$ for the forest stand ages among forest types.

$$
\varepsilon_{\max }=\frac{N P P * \varepsilon_{a}}{N P P_{m}}
$$

where NPP is the field observation data of NPP, $\mathrm{NPP}_{m}$ is the estimated NPP based on the meteorological data and the remote sensing data (NDVI), $\varepsilon_{\mathrm{a}}$ is the fixed value for all the vegetation types and all the forest age, and here the value is 0.43 .

The $\mathrm{NPP}_{\mathrm{m}}$ is separated by the forest types and the forest stand ages, thus the $\varepsilon_{\max }$ for different forest types and the forest stand ages have different values. The $\varepsilon_{\max }$ of various field observation sites are grouped by the forest types and the forest stand ages.

To investigate the relationship between the forest stand ages and the $\varepsilon_{\max }$, the forest stand ages were separated into 12 groups. The forest stand ages that less than 15 years are regarded as group 1, and the forest stand ages between the 15years and the 30 years were regarded as group $2, \cdots$, and the forest stand ages more than 165 years are regarded as group 12 .

\section{RESULTS}

\subsection{The estimated NPP of the forest types}

Based on the remote sensing data and the meteorological data, the NPP of China from 1982 to 2005 was estimated. Based on the available filed observation data of NPP, the selected forest types include the evergreen needleleaf forest (ENF), the evergreen broadleaf forest $(\mathrm{EBF})$ and the deciduous broadleaf forest $(\mathrm{DBF})$. The spatial distribution of the forest types is shown in Fig.1. 


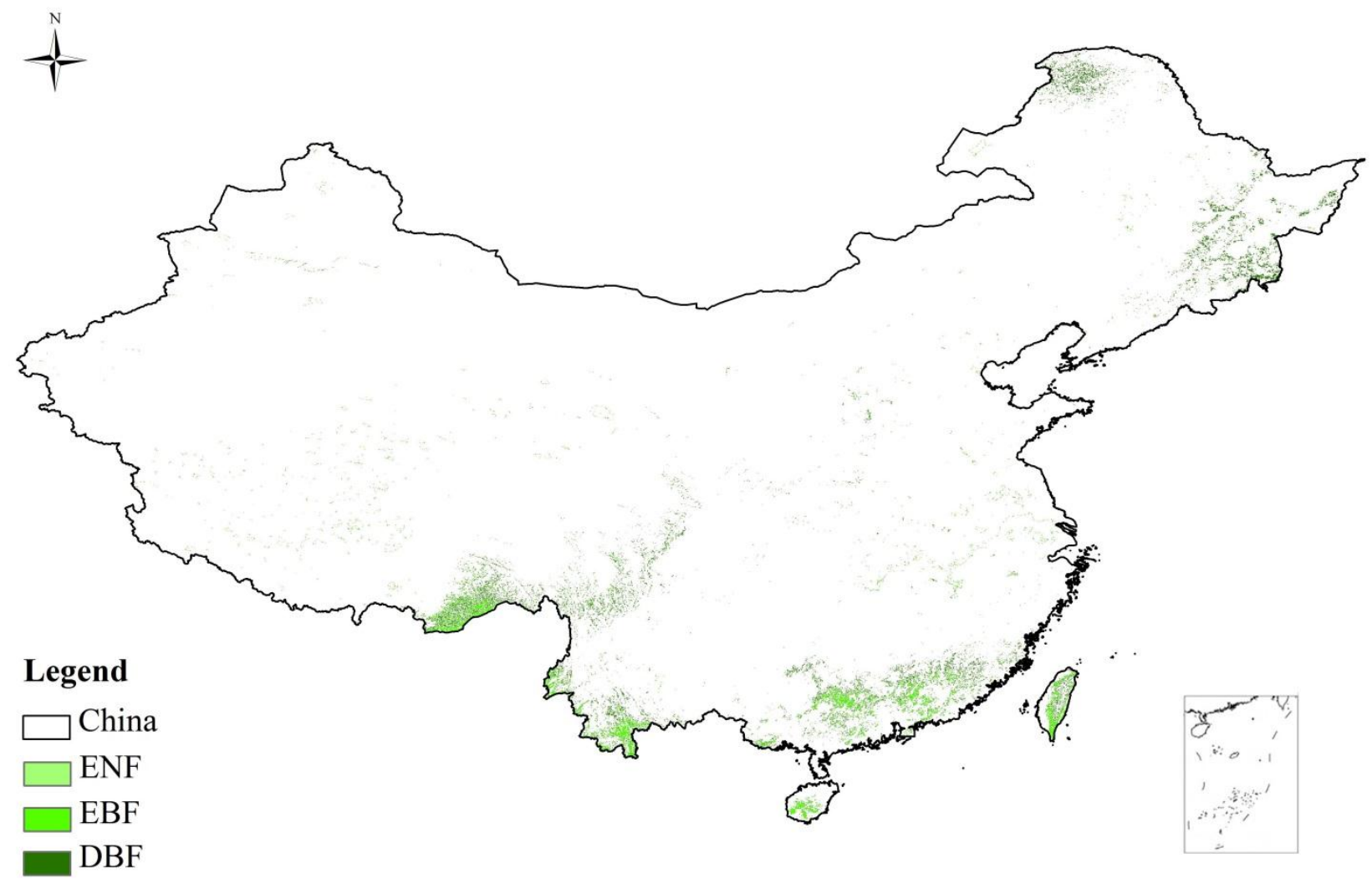

Figure 1. The spatial distribution of three selected forests in China

\begin{tabular}{cc}
\hline The forest types & $\mathrm{NPP}\left(\mathrm{gC} \mathrm{m}^{-2} \mathrm{a}^{-1}\right)$ \\
\hline ENF & 388 \\
EBF & 438 \\
DBF & 420 \\
\hline
\end{tabular}

Table 1 The estimated NPP based on the constant $\varepsilon_{\max }$ for three forest types

The forest is major in South China, and there are still some forests in Northeast China. The evergreen needleleaf forest mainly distributes in the east of China, and some north regions in China. The evergreen broadleaf forest is mainly in the South China, and also some places in the east China. The deciduous broadleaf forest is usually located in South China, and the northeast China.

The estimated NPP based on the constant maximum light-use efficiency $\left(\varepsilon_{\max }\right)$ vary for different forest types. For the evergreen needleleaf forest, the average NPP during the period 1982 to 2005 is about $388 \mathrm{gC} \mathrm{m}^{-2} \mathrm{a}^{-1}$. For the evergreen broadleaf forest, the average NPP is about $438 \mathrm{gCm}^{-2} \mathrm{a}^{-1}$. For the deciduous broadleaf forest, the average NPP is about 420 $\mathrm{gCm}^{-2} \mathrm{a}^{-1}$ (Table 1). The evergreen broadleaf forest has the largest NPP than the other two forest types, and the evergreen needleleaf forest has the least NPP based on the constant $\varepsilon_{\max }$.

\subsection{The relationship between the maximum light-use efficiency $\left(\varepsilon_{\max }\right)$ and the forest stand ages}

The maximum light-use efficiency $\left(\varepsilon_{\max }\right)$ of different stand ages is based on the field observation data NPP. The field observation data NPP is separated by different forest types, and then grouped by the forest stand ages. The number of the study sites in different forest stand ages is also summed up. Here we investigate three forest types including the evergreen broadleaf forest $(\mathrm{EBF})$, the deciduous broadleaf forest $(\mathrm{DBF})$ and the evergreen needle forest (ENF). The relationship between the $\varepsilon_{\max }$ and the forest stand ages for three forest types ate shown in Fig. 2. 

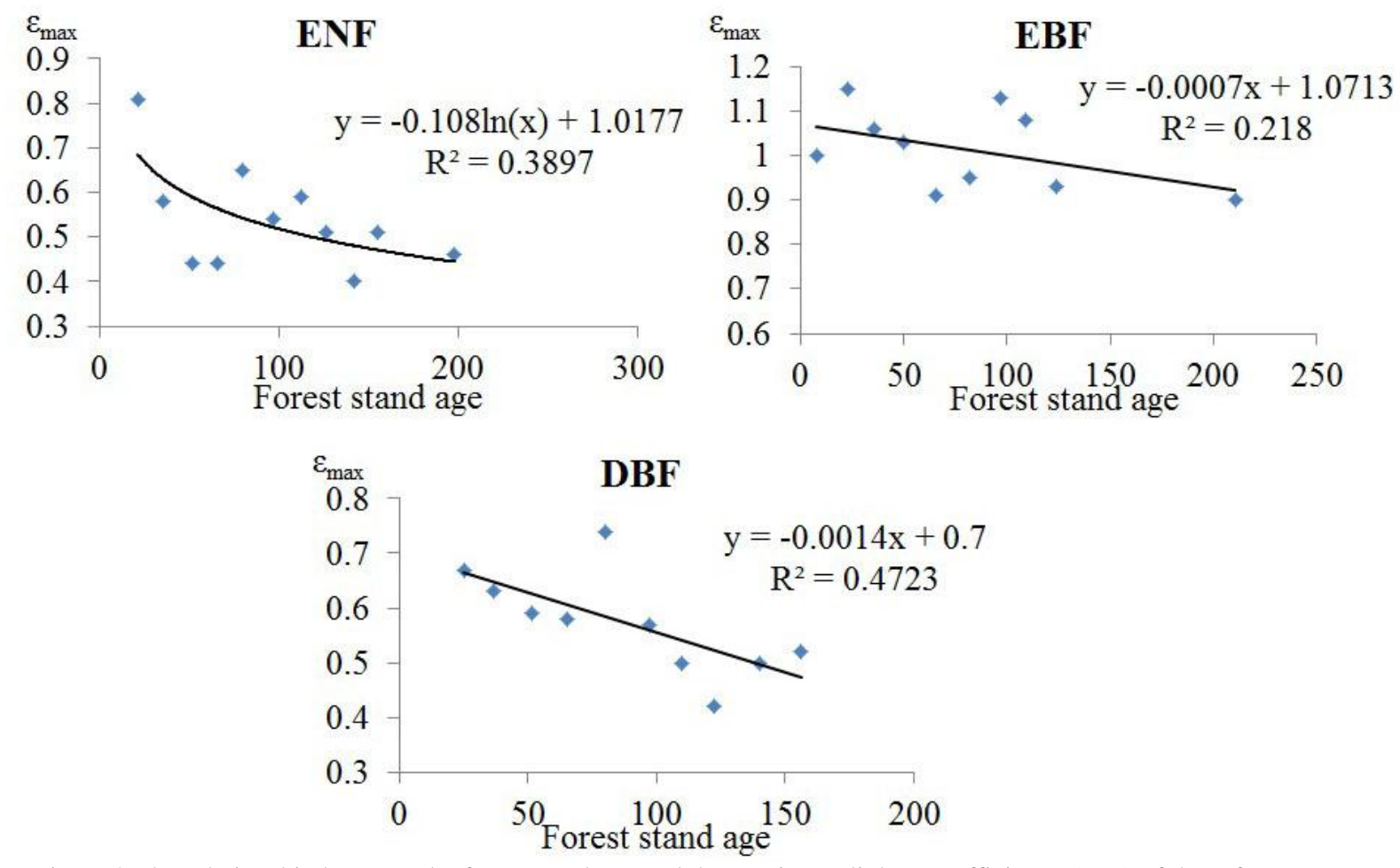

Figure 2 The relationship between the forest stand age and the maximum light-use efficiency $\left(\varepsilon_{\max }\right)$ of three forest types

From Fig.2, The regression equation of the evergreen needleleaf forest is $\mathrm{y}=-0.108 * \ln (\mathrm{x})+1.0177$. The determination of the correlation coefficients $\left(\mathrm{R}^{2}\right)$ is 0.3897 . The $\varepsilon_{\max }$ has decreased as the forest ages increase, but the relationship between the $\varepsilon_{\max }$ and the forest stand ages are non-linear. The regression equation of the evergreen broadleaf forest is $\mathrm{y}=-0.0007 * \mathrm{x}+1.0713$. The $\mathrm{R}^{2}$ is 0.218 . The $\varepsilon_{\max }$ has decreased as the forest stand ages increase, and the relationship is linear. The regression equation of the deciduous broadleaf forest is $\mathrm{y}=-0.0014 * \mathrm{x}+0.7$. The $\mathrm{R}^{2}$ is 0.4723 . The $\varepsilon_{\max }$ has decreased as the forest ages increase, and the slope is higher than the evergreen broadleaf forest. The relationship between the $\varepsilon_{\max }$ and the forest stand ages are also linear.

\subsection{The maximum light-use efficiency $\left(\varepsilon_{\max }\right)$ of forests in different stand ages}

The corrected maximum light-use efficiency $\left(\varepsilon_{\max }\right)$ has indicated that the great differences exist among different forest types. Based on the research data about the forest stand ages in China, the forest stand ages are first separated by the forest types, and then grouped by the young forest, middle-aged forest and the mature forest. For the deciduous broadleaf forest, the average $\varepsilon_{\max }$ of young, middle-aged and mature forest are $0.68,0.65$ and $0.60 \mathrm{gC} \mathrm{MJ}^{-1}$. For the evergreen broadleaf forest, the average $\varepsilon_{\max }$ of young, middle-aged and mature forests are $1.05,1.01$ and $0.99 \mathrm{gC} \mathrm{MJ}^{-1}$. For the evergreen needleleaf forest, the average $\varepsilon_{\max }$ of young, middle-aged and mature forests are 0.72 , 0.57 and $0.52 \mathrm{gC} \mathrm{MJ}^{-1}$. In general, the average $\varepsilon_{\max }$ of evergreen broadleaf forest is larger than the deciduous broadleaf forest, and the minimum of the average $\varepsilon_{\max }$ is the evergreen needleleaf forest. The average $\varepsilon_{\max }$ of young forest is higher than the middle-aged forest, and the mature forest has the lowest $\varepsilon_{\max }$.

\subsection{The estimated forest age-dependent NPP}

The maximum light-use efficiency $\left(\varepsilon_{\max }\right)$ of the young, middle-aged and the mature forests are separated by the forest stand ages, and the forest types including the evergreen needleleaf forest, the evergreen broadleaf forest and the deciduous broadleaf forest are also considered in the study. Based on the estimated NPP of forest types and the $\varepsilon_{\max }$ of different stand ages, the estimated NPP of different stand ages are calculated. For the evergreen needleleaf forest, the estimated NPP of young, middle-aged and mature forest are about $650 \mathrm{gC}$ $\mathrm{m}^{-2} \mathrm{a}^{-1}, 514 \mathrm{gC} \mathrm{m}^{-2} \mathrm{a}^{-1}$ and $469 \mathrm{gC} \mathrm{m}^{-2} \mathrm{a}^{-1}$. For the evergreen broadleaf forest, the estimated NPP of young, middle-aged and mature forest are about $1069 \mathrm{gC} \mathrm{m}^{-2} \mathrm{a}^{-1}, 1028 \mathrm{gC} \mathrm{m}^{-2} \mathrm{a}^{-1}$ and $1008 \mathrm{gC} \mathrm{m}^{-2} \mathrm{a}^{-1}$. For the deciduous broadleaf forest, the estimated NPP of young, middle-aged and mature forest are about $664 \mathrm{gC} \mathrm{m}^{-2} \mathrm{a}^{-1}, 635 \mathrm{gC} \mathrm{m}^{-2} \mathrm{a}^{-1}$ and $586 \mathrm{gC} \mathrm{m}^{-2} \mathrm{a}^{-1}$.

\section{DISCUSSION}

The NPP is the key indicator to reflect the ecosystem performance to the climate change, and the accurate estimate of NPP is significant to regulate the global carbon balance. The forest ecosystem is essential to the world carbon cycle, and the NPP of forest ecosystem has explained about $65 \%$ of the terrestrial ecosystem. The CASA model is widely used to monitor NPP, and the factor that has the largest effect on the estimated NPP based on the CASA model is the maximum light-use efficiency $\left(\varepsilon_{\max }\right)$. The $\varepsilon_{\max }$ varies for different vegetation types which have been investigated by many studies, but the $\varepsilon_{\max }$ can also be different for the various stand ages of forest types. This study focused on the maximum light-use efficiency of the different stand ages among three forest types in China. The evergreen needleleaf forest and the evergreen broadleaf forest have the linear relationship between the forest stand ages and the $\varepsilon_{\max }$, and the deciduous broadleaf forest has the non-linear relationship. The determination of the relationship is based on the $\mathrm{R}^{2}$ of the equation, and the deciduous broadleaf forest has better result when applied the non-linear relationship. The evergreen broadleaf forest has the higher $\varepsilon_{\max }$ than the evergreen needleleaf forest and the 
deciduous broadleaf forest. The $\varepsilon_{\max }$ of evergreen broadleaf forest is always underestimated by the constant $\varepsilon_{\max }$, which will also lead to the underestimate of NPP. The evergreen broadleaf forest has the maximum deviation of the NPP for the young, middle-aged and the mature forest. The $\varepsilon_{\max }$ of the evergreen broadleaf forest among the young, middle-aged and the mature forest change little, but it also has the decreased trend as the forest stand ages increase. The $\varepsilon_{\max }$ of evergreen needleleaf forest is a little estimated by the constant $\varepsilon_{\max }$, and the NPP is also underestimated. The $\varepsilon_{\max }$ of the evergreen broadleaf forest among the young, middle-aged and the mature forest has the decreased trend, and the change is higher than the other two forest types. The $\varepsilon_{\max }$ of deciduous broadleaf forest is underestimated, and it also has the decreased trend from the young forest to the mature forest. In general, the estimated NPP based on the constant $\varepsilon_{\max }$ are underestimated especially for the young and middle-aged forest. For the evergreen needleleaf forest, the deviation of the NPP in young and middle-aged forest is about $262 \mathrm{gC} \mathrm{m}^{-2} \mathrm{a}^{-1}$ and $126 \mathrm{gC} \mathrm{m}^{-2} \mathrm{a}^{-1}$. For the evergreen broadleaf forest, the deviation of the NPP is about $600 \mathrm{gC} \mathrm{m}^{-2} \mathrm{a}^{-1}$ for the young and middle-aged forest. For the deciduous broadleaf forest, the deviation of the NPP in young and middle-aged forest is about $240 \mathrm{gC} \mathrm{m}^{-2} \mathrm{a}^{-1}$. The evergreen broadleaf forest has the largest deviation in NPP, and the young forest for the forest types have higher deviation of NPP than the middle-aged forest and the mature forest. Young forests and middle-aged forests had higher $\varepsilon_{\max }$, and they are more sensitive to climate change. The NPP of young and middle-aged forest should consider the variation of the forest stand age.

\section{CONCLUSION}

This study employed both the meteorological data and the remote sensing data to estimate the NPP of three forest types including the evergreen needleleaf forest (ENF), evergreen broadleaf forest (EBF) and deciduous broadleaf forest (DBF) based on the CASA model. The original CASA model based on the fixed maximum light-use efficiency $\left(\varepsilon_{\max }\right)$ does not consider the effect of the forest stand ages among forest types, and it will lead to the deviation in the estimate of NPP. This study first estimate the NPP based on the CASA model and then employed field observations to inversely estimate the parameter of maximum light-use efficiency of forests in different stand ages. The relationship between maximum light-use efficiency and the forest stand ages was functioned to estimate forest age-dependent NPP. The results showed that $\varepsilon_{\max }$ has changed according to forest types and forest stand ages. The deciduous broadleaf forest, evergreen broadleaf forest and evergreen needleleaf forest all have decreased trend as the forest stand ages increase. The evergreen broadleaf forest has the higher $\varepsilon_{\max }$ than the other two forest types. For deciduous broadleaf forest, the average $\varepsilon_{\max }$ of young, middle-aged and mature forest are $0.68,0.65$ and $0.60 \mathrm{gC} \mathrm{MJ}^{-1}$. For evergreen broadleaf forest, the average $\varepsilon_{\max }$ of young, middle-aged and mature forests are 1.05, 1.01 and $0.99 \mathrm{gC} \mathrm{MJ}^{-1}$. For evergreen needleleaf forest, the average $\varepsilon_{\max }$ of young, middle-aged and mature forests are 0.72 , 0.57 and $0.52 \mathrm{gC} \mathrm{MJ}^{-1}$. The evergreen broadleaf forest has the largest deviation in NPP, and the young forest for the forest types have higher deviation of NPP than the middle-aged forest and the mature forest. Young forests and middle-aged forests had higher $\varepsilon_{\max }$, and they were more sensitive to trends and fluctuations of climate change, so they led to greater annual fluctuations of NPP. These findings confirm the importance of considering the forest stand ages to the estimation of NPP and they are significant to study the response of forests to climate change.

\section{ACKNOWLEDGEMENTS}

This work was supported by the Fund for Creative Research Groups of National Natural Science Foundation of China (No. 41321001), the National Basic Research Program of China (No. 2012CB955401), the National Natural Science Foundation of China (No. 30970514), and the New Century Excellent Talents in University (No. NCET-10-0251).

\section{REFERENCES}

Beck H E, McVicar T R, Dijk A I J M, Schellekens J, Jeu R A M, and Bruijnzeel L, 2011. Global evaluation of four AVHRR-NDVI data sets: Intercomparison and assessment against Landsat imagery. Remote Sensing of Environment. 115(10), pp. 2547-2563.

Chen J M, Ju W M, Cihlar J, Price D, Liu J, Chen W J, Pan J J, Black A and Barr A, 2003. Spatial distribution of carbon sources and sinks in Canada' $\mathrm{s}$ forests. Tellus Series B Chemical and Physical Meteorology. 55(2), pp. 622-641.

Eidenshink J C, 1992. The 1990 conterminous U.S. AVHRR data set. Photogrammetric Engineering and Remote Sensing, 58, pp. 809-813.

Gower S T, McMurtrie R E and Murty D, 1996. Aboveground net primary production decline with stand age: potential causes. Trends in Ecology and Evolution. 11, pp. 378-382.

Hao Y P, Chen Y F and Zhang X Y, 1998. Progress in estimation of net primary productivity and its responses to climatic change. Advanced Earth Science, 13(6), pp. 564-571.

Holben B N, 1986. Characteristics of maximum-value composite images from temporal AVHRR data. International Journal of Remote Sensing, 7, pp. 1417-1434.

Hui D F, Wang J, Le X, Shen W J and Ren H, 2012. Influences of biotic and abiotic factors on the relationship between tree productivity and biomass in China. Forest Ecology and Management, 264, pp. 72-80.

Kashian D M, Romme W H, Tinker D B and Turner M G, 2006. Carbon storage on landscapes with stand-replacing fires. BioScience. 56, pp. 598-606.

Li X J, Zhou T and He X Z, 2009. Carbon sink of forest ecosystem driven by NPP increasing in China. Journal of Natural Resources, 24(3), pp. 491-497.

Liu C Y, Dong X F and Liu Y Y, 2015. Changes of NPP and their relationship to climate factors based on the transformation of different scales in Gansu, China. Catena, 125, pp. 190-199. Liang W, Yang Y T, Fan D M, Guan H D, Zhang T, Long D, Zhou Y and Bai D, 2015. Analysis of spatial and temporal patterns of net primary production and their climate controls in China from 1982 to 2010. Agricultural and Forest Meteorology. 204, pp. 22-36.

Liu C Y, Dong X F and Liu Y Y, 2015. Changes of NPP and their relationship to climate factors based on the transformation of different scales in Gansu, China. Catena. 125, pp. 190-199.

Lobell D B, Hicke J A, Asner G P, Field C B, Tucker C J and Los S O, 2002. Satellite estimates of productivity and light-use efficiency in United States agriculture 1982-1998. Global Change Biology. 8, pp. 722-735.

Piao S L, Fang J Y and Guo Q H, 2001. Application of CASA model to the estimation of Chinese terrestrial net primary productivity. Acta Phytoecologica Sinica. 25(5), pp. 603-608.

Piao S L, Ciais P, Friedlingstein P et al. 2008. Net carbon dioxide losses of northern ecosystems in response to autumn warming. Nature. 451, pp. 49-53. 
Potter C S, Randerson J T, Field C B, Matson P A, Vitousek P M, Mooney H A and Klooster S A, 1993. Terrestrial ecosystem production: a process model based on global satellite and surface data. Global Biogeochemistry Cycles. 7(4), pp. 811-841. Song $\mathrm{C} \mathrm{H}$ and Woodcock, 2003. A regional forest ecosystem carbon budget model: impacts of forest age structure and landuse history. Ecological Modelling. 164, pp. 33-47.

Tucker C J, Pinzon J E, and Brown M E, Slayback, D A, Pak E W, Mahoney R, Vermote E and Saleous N E, 2005. An extended AVHRR 8-km NDVI dataset compatible with MODIS and SPOT vegetation NDVI data. International Journal of Remote Sensing. 26(20): pp. 4485-4498.

Wang S Q, Zhou L, Chen L M, Ju W M, Feng X F and Wu W X 2011. Relationships between net primary productivity and stand age for several forest types and their influence on China's carbon balance. Forest of Environmental Management. 92, pp. 1651-1662.

Waring R H and Schlesinger W H, 1985. Forest ecosystems: concepts and management. Academic Press, New York.

Yu M X, Li Q F, Hayes M J, Svoboda M D and Heim R R, 2014. Are droughts becoming more frequent or severe in China based on the Standardized Precipitation Evapotranspiration Index: 1951-2010? International Journal of Climatology. 34(3): pp. $545-558$.

Zhang L X, Zhou D C, Fan J W and Hu Z M, 2015. Comparison of four light-use efficiency models for estimating terrestrial gross primary production. Ecological Modelling. 300, pp. 30-39.

Zhu W Q, Pan Y Z, He H, Yu D Y and Hu H B, 2006. Simulation of maximum light-use efficiency for some typical vegetation types in China. Chinese Science Bulletin. 51(6), pp. 701-706. 